\title{
Chinese soft-shelled turtle egg powder lowers serum cholesterol, increases faecal neutral steroids and bile acid excretion, and up-regulates liver cytochrome P450 mRNA level in rats
}

\author{
Yu Huanling ${ }^{1}$, Li Yong ${ }^{1 *}$, Wang Junbo ${ }^{1}$, Zheng Liping ${ }^{1}$ and Yan Weixing ${ }^{2}$ \\ ${ }^{1}$ Department of Nutrition and Food Hygiene, School of Public Health, Peking University Health Science Center, 38 Xue Yuan Road, \\ Beijing 100083, China \\ ${ }^{2}$ Institution of Nutrition and Food Safety, Chinese Center for Disease Control and Prevention, Beijing, China
}

(Received 13 October 2004 - Revised 23 February 2005 - Accepted 15 March 2005)

\begin{abstract}
The aim of the present study was to investigate the effect of Chinese soft-shelled turtle whole egg powder (TE) on cholesterol metabolism in SpragueDawley rats to determine whether it has a cholesterol-lowering effect. Forty male Sprague-Dawley rats were fed a high-fat diet supplemented with TE $(0,0.75,1.50$ or $3.00 \mathrm{~g} / \mathrm{kg}$ body weight) administrated by gavage for 24 weeks. Serum total cholesterol (TC), HDL-cholesterol (HDL-C), LDL-cholesterol (LDL-C) and faecal total bile acids levels were determined by enzymatic methods. Faecal steroid concentrations were measured by GC. Means and standard deviations were calculated where appropriate for values, and the data were tested by one-way ANOVA. After 24 weeks of feeding a high-fat diet with TE supplementation, serum TC and LDL-C levels, liver cholesterol and liver lipid levels were reduced in rats. TE supplementation did not affect the faecal output, but significantly increased steroid concentrations in faeces, indicating increased steroids excretion. The faecal bile acid excretion was also increased as evidence by elevated mRNA level of liver cytochrome P450, family 7, subfamily A, polypeptide 1. Our results demonstrated that the TE does have a cholesterol-lowering effect by increasing the excretion of total bile acids and neutral steroids.
\end{abstract}

Lipid-lowering: Faecal bile acid: Steroids: Low cholesterol

One of the basic theories of nutrition in traditional Chinese medicine is food as tonic. Food as tonic refers to using food to make a person stronger and feel better in general. Chinese soft-shelled turtle has always been viewed as this kind of food and has been eaten for thousands of years in China. It has been believed to nourish yin (body fluid) and enhance liver function to make a person feel calmer. The eggs of the turtle are also thought to nourish yin and supplement deficiency. The medicinal effects of turtle eggs have been depicted in Materia Medica.

A number of risk factors are known to contribute to CVD. Elevated levels of plasma total cholesterol (TC) and lower LDL-cholesterol (LDL-C) have long been viewed as primary risk factors for CVD (Consensus Conference, 1995). To avoid the side-effects of lipid-lowering pharmacological drugs, reduction in TC and LDL-C levels can be achieved by dietary means. It has been shown that soya protein, fish protein, PUFA, egg lecithin, dietary fibres and plant sterols can lower cholesterol levels in animal models and human subjects (Fukushima et al. 2000; Tammi et al. 2001; Blair et al. 2002; Garg et al. 2003; Noh \& Koo, 2003; Wergedahl et al. 2004). The mechanisms of reducing plasma cholesterol by soya protein include inducing LDL receptor expression, increasing bile acid synthesis, and decreasing steroid absorption from the intestine (Potter, 1995). Several studies suggest that the amino acids or peptide of soya protein might be responsible for the changes in blood lipids (Kern et al. 2002). Although the cholesterol-lowering effect of soya protein is well known, only a few studies have been performed on the lipid-lowering effects of other proteins, such as fish protein (Zhang \& Beynen, 1993; Wergedahl et al. 2004), white lupin seed proteins (Sirtori et al. 2004) and buckwheat protein (Tomotake et al. 2000).

The amino acids profile of turtle egg protein is unique, and its phosphatidylcholine content is rich and cholesterol content is very low. Can it change blood lipids? It has not been studied extensively. Although the search for natural substances capable of lowering blood cholesterol is ongoing in the field of nutrition, research on whole foods containing more than one factor with potential cholesterol-lowering effect is scanty. The objective of the present study was to determine whether Chinese soft-shelled turtle whole egg powder (TE) can lower serum lipids and undertake a preliminary investigation of its mechanism.

\section{Materials and methods \\ Preparation of Chinese soft-shelled turtle whole egg powder \\ Turtle egg powder was prepared as follows. Before freeze-drying, the turtle eggs were washed with water and crushed into small pieces, which were filtered through an 80 mesh sieve. The egg}

Abbreviations: ABCA1, ATP-binding cassette transporter 1; BW, body weight; CYP7A1, cytochrome P450, family 7, subfamily A, polypeptide 1; GAPDH, glyceraldehyde-3phosphate dehydrogenase; HDL-C, HDL-cholesterol; HMG, 3-hydroxy-3-methylglutaryl; LDL-C, LDL-cholesterol; LXR- $\alpha$, liver X receptor $\alpha$; TC, total cholesterol; TE, Chinese soft-shelled turtle whole egg powder.

* Corresponding author: Professor Li Yong, fax +8610 82801177, email liyong@bjmu.edu.cn 
suspension obtained was frozen at $-80^{\circ} \mathrm{C}$ for $72 \mathrm{~h}$ and then the samples were transferred to a freeze-dryer and dehydrated. The freeze-dried turtle egg samples were then rapidly powdered, and the resulting powder was stored desiccated at $-20^{\circ} \mathrm{C}$ in sealed plastic bags. The amino acid and fatty acid composition of TE is shown in Table 1 .

\section{Animal and diets}

Male Sprague-Dawley rats (Experimental Animal Breeding Center, Peking University, Beijing, China) weighing 160-180g were fed a chow diet (Table 2) for $7 \mathrm{~d}$, then fed a high-fat diet (10\% lard, $10 \%$ yolk powder, $1 \%$ cholesterol, $79 \%$ chow). The rats were maintained at $22 \pm 2^{\circ} \mathrm{C}$ and $60 \pm 5 \%$ relative humidity in

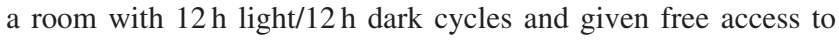
food and water at all times. Rats were divided according to serum LDL-C level and weight into four groups of ten rats each and fed the high-fat diet supplemented with TE $(0,0.75,1.5$ or $3.0 \mathrm{~g} / \mathrm{kg}$ body weight (BW)) administrated by gavage. BW and food intake were recorded weekly during the 24 -week study. During the last $7 \mathrm{~d}$ of the experimental period, faecal samples were collected from each cage, pooled and then stored at $-20^{\circ} \mathrm{C}$ until analysis. At the end of the experiment, rats were deprived of food for $16 \mathrm{~h}$ and blood samples were collected into tubes by femoral puncture and centrifuged at $4^{\circ} \mathrm{C}$ for $15 \mathrm{~min}$ at $4000 \mathrm{rpm}$. Before blood sampling, the rats were anaesthetized by sodium pentobarbital ( $40 \mathrm{mg} / \mathrm{kg} \mathrm{BW}$ ). After collecting the blood, the livers were removed and weighed and first being washed in ice-cold $0.9 \% \mathrm{NaCl}$ and then stored at $-80^{\circ} \mathrm{C}$ until analysis. All animals were handled in accordance with the guidelines established by the Chinese Committee on Experimental Animal Supervision.

\section{Serum total cholesterol, HDL-cholesterol and LDL-cholesterol}

Serum TC was determined without extraction by an enzymatic colorimetric method using a kit (\#CH3810) provided by Randox Co. (Crumlin, County Antrim, UK). HDL-cholesterol (HDL-C) (kit \#CH3811; Randox Co.) and LDL-C (kit \#CH3841; Randox Co.) were determined after precipitation with magnesium phosphotungstic acid. All these were accomplished in an automatic machine (7020 Clinical Analyzer; Hitachi, Tokyo, Japan).

Table 1. Amino acid and fatty acid $^{*}$ content of Chinese soft-shelled turtle egg $(\mathrm{g} / 100 \mathrm{~g})$

\begin{tabular}{lclc}
\hline Amino acid & Content & Fatty acid & Content \\
\hline Leucine & 2.86 & Myristic acid & 0.44 \\
Isoleucine & 1.77 & Palmitic acid & 3.14 \\
Lysine & 2.99 & Stearic acid & 0.87 \\
Methionine & 0.76 & Palmitoleic acid & 1.88 \\
Cysteine & 0.80 & Heptadecenoic acid & 0.15 \\
Phenylalanine & 1.52 & Oleic acid & 11.8 \\
Tyrosine & 1.63 & Eicosenoic acid & 0.20 \\
Threonine & 1.69 & Linoleic acid & 0.86 \\
Tryptophan & 0.47 & Linolenic acid & 0.12 \\
Valine & 1.86 & Arachidic acid & 0.42 \\
Histidine & 1.01 & EPA & 1.14 \\
Arginine & 2.51 & Docosapentaenoic acid & 0.44 \\
Alanine & 1.93 & DHA & 1.27 \\
Aspartic acid & 2.94 & Phospholipid & 3.79 \\
Glutamic acid & 3.97 & Phosphatidylcholine & 2.61 \\
Glycine & 1.08 & Cholesterol & 0.85 \\
Proline & 1.90 & & \\
Serine & 3.96 & & \\
\hline
\end{tabular}

* Fatty acid content less than $0.1 \mathrm{~g} / 100 \mathrm{~g}$ not listed.
Table 2. Composition of the chow diet

\begin{tabular}{lc}
\hline Nutrient & Content \\
\hline Protein (\%) & 20.26 \\
Fat (\%) & 4.24 \\
Carbohydrate (\%) & 25.19 \\
Vitamin A mg/100 g & 3.6 \\
Vitamin D mg/100 g & 0.25 \\
Vitamin E mg/100 g & 44.0 \\
Vitamin K mg/100 g & 5.0 \\
Choline chloride $(\mathrm{g} / \mathrm{kg})$ & 1.10 \\
Mineral mix $(\mathrm{g} / \mathrm{kg})$ & 25.90 \\
\hline
\end{tabular}

For details of diets and procedures, see p. 314 of proofs

\section{Liver total lipids, total cholesterol and triacylglycerols}

Liver total lipids were determined according to Folch et al. (1957). Liver TC concentration was determined using the same kit as for serum TC following extraction of liver samples with methanol-chloroform $(2: 1, \mathrm{v} / \mathrm{v})$. Liver triacylglycerol concentration was determined using a kit provided by Randox Co. (kit \#TR1697) after extraction with methanol-chloroform (2:1, v/v).

\section{Analysis of faecal neutral steroids}

Faecal steroids were obtained from dried faeces according to Folch et al. (1957) using the following procedures (Schneider et al. 2000). An aliquot of dried faeces $(100 \mathrm{mg})$ was extracted with methanol-chloroform $(2: 1, \mathrm{v} / \mathrm{v})$ containing $5 \alpha$-cholestane (Sigma-Aldrich, St. Louis, MO, USA) and the sample saponified in $2 \mathrm{ml}$ methanolic $\mathrm{KOH}$ for $2 \mathrm{~h}$ at $50^{\circ} \mathrm{C}$. After cooling to ambient temperature and adding $2.0 \mathrm{ml}$ deionized water, the lipids were extracted into $5 \mathrm{ml}$ hexane. The sample was derivatized before GC by adding $100 \mu l$ pyridine (Fluka, Buchs, Switzerland), followed by $50 \mu$ l Sylon BTZ (Supelco, Bellefonte, PA, USA). GC analyses were carried out using a CP-3800 with a DB-1 capillary column $(30 \mathrm{~m}, 0.25 \mathrm{~mm}$ inner diameter) (Varian, Palo Alto, CA, USA). The temperature programme started at $90^{\circ} \mathrm{C}$; after an initial hold of $1 \mathrm{~min}$, the oven was programmed to $285^{\circ} \mathrm{C}$ ( $30 \mathrm{~min}$ ) at a rate of $15^{\circ} \mathrm{C} / \mathrm{min}$. $\mathrm{H}_{2}$ was used as carrier gas.

\section{Faecal bile acids}

Faeces were extracted by the method of Setchell et al. (1983), and the extracted solutions were used to determine bile acids concentration (Ausbio Laboratories Ltd, Beijing, China) enzymatically.

\section{Semi-quantitative $R T-P C R$}

Total RNA was purified using Trizol (Invitrogen, Carlsbad, CA, USA) and reverse-transcribed using a Reverse Transcriptase kit (\#A3500; Applied Promega, Madison, WI, USA). RNA encoding 3-hydroxy-3-methylglutaryl (HMG)-CoA reductase, cholesterol $7 \alpha$-hydroxylase (CYP7A1: cytochrome P450, family 7, subfamily A, polypeptide 1), ATP-binding cassette transporter 1 (ABCA1), liver X receptor $\alpha(\mathrm{LXR}-\alpha)$ and glyceraldehyde-3-phosphate dehydrogenase (GAPDH; used as an invariant control) were analysed by semi-quantitative RT-PCR. The primer sequences are listed in Table 3. PCR was carried out as follows: denature at $94^{\circ} \mathrm{C}$ for $5 \mathrm{~min}$ for the first cycle, and then cycles consisting of $94^{\circ} \mathrm{C}$ for $1 \mathrm{~min}$, annealing at $60^{\circ} \mathrm{C}$ for $1 \mathrm{~min}$, and extension at $72^{\circ} \mathrm{C}$ for $2 \mathrm{~min}$. Twenty-five cycles were performed for GAPDH and CYP7A1, thirty cycles for LXR- $\alpha$, thirty-five cycles for 
Table 3. Primer sequences used in mRNA quantification by RT-PCR

\begin{tabular}{|c|c|c|c|}
\hline ABCA1 & 5'-GTG AAC TTT GCC AAG GAC CA-3' & 5'-AGG CTA CAA AGG CAC TGC C-3' & Qiu et al. (2001) \\
\hline CYP7A1 & 5'-GCC GTC CAA GAA ATC AAG CAG T-3' & 5'-TGT GGG CAG CGA GAA CAA AGT-3' & Fukushima et al. (2000) \\
\hline HMG-CoA & $5^{\prime}$-GCG TGC AAA GAC AAT CCT GGA G $-3^{\prime}$ & $5^{\prime}$-GTT AGA CCT TGA GAA CCC AAT G $-3^{\prime}$ & Fukushima et al. (2000) \\
\hline LXR- $\alpha$ & 5'-GAG TTG TGG AAG ACA GAA CCT CAA-3' & 5'-GGG CAT CCT GGC TTC CTC-3' & Steffensen et al. (2003) \\
\hline GAPDH & 5'-GCC ATC AAC GAC CCC TTC ATT-3' & 5'-CGC CTG CTT CAC CAC CTT CTT-3' & Fukushima et al. (2000) \\
\hline
\end{tabular}

HMG-CoA reductase and twenty-six cycles for ABCA1. Amplification products were electrophoresed on a $1.5 \%$ agarose gel and the relative quantity of mRNA was estimated by densitometry scanning with X-rays (Smart view 2002 program; Shanghai FURI Science and Technology Co. Ltd., Shanghai, China).

\section{Statistical analysis}

Values are presented as means and standard deviations and, where appropriate, data were tested by one-way ANOVA using the LSD procedure of the SPSS10.0 package (SPSS Inc, Chicago, IL, USA). Individual comparisons were made by least-squares means. Differences with $P<0.05$ were considered significant.

\section{Results}

Food intake and body weight

Supplementation with different TE levels did not affect food intake or BW gain and food efficiency of the rats (Table 4).

\section{Serum lipids}

In Sprague-Dawley rats supplemented with 1.5 and $3.0 \mathrm{~g} \mathrm{TE} / \mathrm{kg}$ $\mathrm{BW}$, serum TC concentrations were significantly reduced by $20 \%(P<0.01)$ and $14 \%(P<0.05)$, respectively (Table 5). Serum LDL-C and HDL-C levels were reduced by $26 \%$ $(P=0.017)$ and $12.5 \%(P=0.052)$ in rats supplemented with $1.5 \mathrm{~g} \mathrm{TE} / \mathrm{kg}$ BW. There was no difference in HDL-C:TC among groups. The largest reductions in serum LDL-C and TC were found in rats supplemented with $1.5 \mathrm{~g}$ TE/ $\mathrm{kg} \mathrm{BW}$.

\section{Liver total lipids, total cholesterol and triacylglycerols}

Relative liver weight of the rats supplemented with $1.5 \mathrm{~g} \mathrm{TE} / \mathrm{kg}$ BW was reduced significantly $(P<0 \cdot 05)$. Liver total lipids, TC and triacylglycerol concentrations were reduced in particular in the livers of rats supplemented with 1.5 and $3.0 \mathrm{~g}$ TE/kg BW (Table 6).

\section{Faecal bile acids and neutral steroids excretion}

Daily faecal output was not different between groups. Both faecal total bile acids concentration $(\mu \mathrm{mol} / \mathrm{g})$ and daily faecal bile acids excretion $(\mu \mathrm{mol} / \mathrm{d})$ were significantly higher $(P<0.05)$ in rats supplemented with 1.5 and $3.0 \mathrm{~g} \mathrm{TE} / \mathrm{kg} \mathrm{BW}$ (Table 7)

Cholesterol, coprostanol and coprostanone were the main neutral steroids in rat faeces. Faecal concentrations and daily excretion of total neutral steroids were both increased significantly $(P<0.01)$ in rats supplemented with 1.5 and $3.0 \mathrm{~g}$ TE/ $/ \mathrm{kg}$ BW (Table 7). Faecal cholesterol and coprostanol daily excretion were increased significantly by $172.6 \%$ and $99.7 \%$, respectively, in rats supplemented with $1.5 \mathrm{~g} \mathrm{TE} / \mathrm{kg} \mathrm{BW}$, and by $81.4 \%$ and $61.4 \%$ in rats supplemented with $3.0 \mathrm{~g}$ TE $/ \mathrm{kg}$ BW (all $P<0 \cdot 01$ ). Furthermore, in rats supplemented with $1.5 \mathrm{~g}$ TE/ $\mathrm{kg} \mathrm{BW}$, the faecal coprostanone excretion was also significantly higher $(P<0.05)$ than in rats without TE supplement. Dietary cholesterol apparently absorbed was lowered by supplementation with TE.

mRNA levels

Although RT-PCR is less sensitive to determine mRNA levels than real-time PCR and other methods, it is also used because of its simplicity and low cost. In the present study, we chose this method to compare the mRNA levels between groups. The results indicated that liver mRNA levels of ABCA1, CYP7A1, HMG-CoA reductase and LXR- $\alpha$ could be quantified by RTPCR. Hepatic CYP7A1 mRNA concentration was up-regulated significantly in rats supplemented with TE $(P=0.062,0.000$ and 0.013 at $0.75,1.5$ and $3.0 \mathrm{~g}$ TE $/ \mathrm{kg} \mathrm{BW}$, respectively). LXR- $\alpha$ was also up-regulated in rats supplemented with $3.0 \mathrm{~g}$ TE/ $/ \mathrm{kg}$

Table 4. Effects of Chinese soft-shelled turtle whole egg powder (TE) on body weight (BW) and food intake in rats (Mean values with their standard deviations for ten animals per group)

\begin{tabular}{|c|c|c|c|c|c|c|c|c|}
\hline & \multicolumn{2}{|c|}{$0 \mathrm{~g} \mathrm{TE} / \mathrm{kg} \mathrm{BW}$} & \multicolumn{2}{|c|}{$0.75 \mathrm{~g} \mathrm{TE} / \mathrm{kg} \mathrm{BW}$} & \multicolumn{2}{|c|}{$1.5 \mathrm{~g} \mathrm{TE} / \mathrm{kg} \mathrm{BW}$} & \multicolumn{2}{|c|}{$3.0 \mathrm{~g} \mathrm{TE} / \mathrm{kg} \mathrm{BW}$} \\
\hline & Mean & SD & Mean & SD & Mean & SD & Mean & SD \\
\hline \multicolumn{9}{|l|}{ Weight (g) } \\
\hline Week 0 & $168 \cdot 4$ & $6 \cdot 4$ & $164 \cdot 4$ & 4.5 & 163.9 & $6 \cdot 4$ & $166 \cdot 5$ & $6 \cdot 6$ \\
\hline Week 24 & $660 \cdot 7$ & $106 \cdot 0$ & 659.6 & $95 \cdot 7$ & $645 \cdot 2$ & $60 \cdot 3$ & $651 \cdot 3$ & $62 \cdot 3$ \\
\hline Weight gain (g) & $492 \cdot 3$ & $95 \cdot 1$ & 495.6 & 87.4 & $482 \cdot 1$ & 91.5 & $498 \cdot 1$ & $62 \cdot 3$ \\
\hline Food intake (g) & $3187 \cdot 3$ & 103.4 & $3101 \cdot 3$ & $109 \cdot 2$ & $2993 \cdot 3$ & 144.8 & $3013 \cdot 8$ & $156 \cdot 2$ \\
\hline Food efficiency (\%) & $16 \cdot 8$ & 0.05 & $16 \cdot 3$ & 0.07 & $16 \cdot 2$ & 0.07 & $16 \cdot 5$ & 0.06 \\
\hline
\end{tabular}

For details of diets and procedures, see p. 314. 
Table 5. Effects of Chinese soft-shelled turtle whole egg powder (TE) on serum lipids in rats

(Mean values with their standard deviations for ten animals per group)

\begin{tabular}{|c|c|c|c|c|c|c|c|c|}
\hline & \multicolumn{2}{|c|}{$0 \mathrm{~g} \mathrm{TE} / \mathrm{kg} \mathrm{BW}$} & \multicolumn{2}{|c|}{$\begin{array}{c}0.75 \mathrm{~g} \mathrm{TE} / \mathrm{kg} \\
\mathrm{BW}\end{array}$} & \multicolumn{2}{|c|}{$1.5 \mathrm{~g} \mathrm{TE} / \mathrm{kg} \mathrm{BW}$} & \multicolumn{2}{|c|}{$3.0 \mathrm{~g} \mathrm{TE} / \mathrm{kg} \mathrm{BW}$} \\
\hline & Mean & SD & Mean & $\mathrm{SD}$ & Mean & SD & Mean & SD \\
\hline \multicolumn{9}{|l|}{$\mathrm{TC}(\mathrm{mmol} / \mathrm{l})$} \\
\hline Week 0 & 1.87 & 0.25 & 1.89 & 0.18 & 1.88 & 0.17 & 1.86 & 0.19 \\
\hline Week 24 & 3.09 & 0.41 & $2 \cdot 75$ & 0.51 & $2 \cdot 47^{\star \star}$ & 0.31 & $2 \cdot 65^{\star}$ & 0.33 \\
\hline HDL-C (mmol/l) & 1.27 & 0.21 & $1 \cdot 19$ & 0.22 & $1 \cdot 11$ & 0.13 & $1 \cdot 17$ & 0.19 \\
\hline LDL-C (mmol/l) & 1.22 & 0.25 & 1.05 & 0.36 & $0.90^{\star}$ & 0.11 & 1.03 & 0.18 \\
\hline HDL-C:TC & 0.42 & 0.06 & 0.44 & 0.08 & 0.45 & 0.04 & 0.45 & 0.05 \\
\hline
\end{tabular}

BW, body weight; TC, total cholesterol; HDL-C, HDL-cholesterol; LDL-C, LDL-cholesterol.

Mean values were significantly different from those of the other groups: ${ }^{*} P<0.05,{ }^{*} P<0.01$.

For details of diets and procedures, see p. 314 of proofs.

BW only ( $P=0 \cdot 016$; Fig. 1). Transcription of other genes was not affected (data not shown).

\section{Discussion}

TE was well tolerated by the Sprague-Dawley rats and did not affect food intake, growth, body or organ weights even at the high dose of $3.0 \mathrm{~g} / \mathrm{kg} \mathrm{BW}$. TE supplementation exerted a significant cholesterol-lowering effect, especially at the doses of 1.5 and $3.0 \mathrm{~g} / \mathrm{kg}$ BW. Moreover, the serum cholesterol change induced by TE has not been described previously.

In the present study, using Sprague-Dawley rats as animal models, we demonstrated the cholesterol-lowering effect of TE. In the rats, supplementation with TE for 24 weeks significantly reduced serum TC and LDL-C levels, and liver lipid and cholesterol concentrations, compared with the control group without TE supplement. A number of studies using different animal models have demonstrated the cholesterol-lowering effects of soya protein, fish protein and white lupin seed protein. Several mechanisms have been shown to explain this effect of soya protein. Enhanced faecal steroid excretion, which is the major route for cholesterol excretion from the body (Huff \& Carroll, 1980), may be one of these mechanisms. In the present study, TE (1.5 and $3.0 \mathrm{~g} / \mathrm{kg} \mathrm{BW}$ ) increased the excretion of steroids, including bile acids and neutral steroids, resulting in significant lowering of serum cholesterol levels. We believe that the TE supplement modified cholesterol metabolism because the faecal steroid concentrations were increased but not the total faecal output.

Methionine has been shown to elevate serum cholesterol concentration (Sugiyama et al. 1986). However, methionine supplementation to a soya diet did not abolish the cholesterol-lowering effects of soya protein relative to casein (Kern et al. 2002), suggesting that some factor other than methionine may be responsible at least in part for the cholesterol-lowering effect of soya protein. However, it was suggested that the higher methionine:glycine in casein may be responsible for the elevation in serum cholesterol (Kritchevsky et al. 1982), and glycine supplementation to a casein-based diet lowered serum cholesterol concentration in rats (Sugiyama et al. 1986). In the present experiment, the methionine:glycine was 0.70 in TE. It is lower than that in casein (2.3) and soya protein supplemented with methionine (1.2; Kern et al. 2002). It was also suggested that the increased serum cholesterol level that occurs with casein feeding was caused by the high lysine:arginine in casein (Berge et al. 1984; Madsen et al. 1998). The lysine:arginine in TE is $1 \cdot 19$, lower than that in casein (1.8), slightly higher than that in fish protein $(1.1$; Wergedahl et al. 2004) and soya protein (0.8), favouring a cholesterol-lowering effect by TE. Thus, the amino acid composition of TE may contribute, at least in part, to its cholesterol-lowering effect.

CYP7A1 is a liver-specific enzyme that catalyses the rate-limiting step in the classic pathway of bile acid synthesis responsible for the conversion of cholesterol to bile acids (Russell \& Setchell, 1992; Kramer et al. 2003), which is the primary mechanism for the removal of cholesterol from the body. This mechanism plays an important role in regulation of bile acid biosynthesis and cholesterol homeostasis. Spady et al. (1995) demonstrated that overexpression of exogenous CYP7A1 genes effectively reduced the plasma cholesterol level in hamsters fed a low- or high-fat diet. Yokogoshi et al. (1999) found that taurine supplementation reduced the rat blood level of cholesterol and induced CYP7A1 activity and CYP7A1 gene expression. Moreover, serum cholesterol level was negatively correlated with CYP7A1 mRNA level. In the present

Table 6. Liver total lipids, total cholesterol and triacylglycerols in rats supplemented with Chinese soft-shelled turtle whole egg powder (TE) for 24 weeks

(Mean values with their standard deviations for ten animals per group)

\begin{tabular}{|c|c|c|c|c|c|c|c|c|}
\hline & \multicolumn{2}{|c|}{$0 \mathrm{~g} \mathrm{TE} / \mathrm{kg} \mathrm{BW}$} & \multicolumn{2}{|c|}{$0.75 \mathrm{~g} \mathrm{TE} / \mathrm{kg} \mathrm{BW}$} & \multicolumn{2}{|c|}{$1.5 \mathrm{~g} \mathrm{TE} / \mathrm{kg} \mathrm{BW}$} & \multicolumn{2}{|c|}{$3.0 \mathrm{~g} \mathrm{TE} / \mathrm{kg} \mathrm{BW}$} \\
\hline & Mean & SD & Mean & SD & Mean & SD & Mean & SD \\
\hline Relative liver weight (g/kg BW) & 37.45 & 7.9 & $36 \cdot 71$ & $7 \cdot 2$ & $31 \cdot 76^{\star}$ & 4.4 & 33.94 & $2 \cdot 9$ \\
\hline Total lipids (g/g wet liver) & 0.4048 & 0.04 & 0.3825 & 0.05 & $0.3253^{*}$ & 0.04 & $0.3494^{*}$ & 0.03 \\
\hline Total cholesterol ( $\mu \mathrm{mol} / \mathrm{g}$ wet liver) & $61 \cdot 35$ & $20 \cdot 38$ & $55 \cdot 73$ & $19 \cdot 44$ & 41.02 & $14 \cdot 79$ & $31 \cdot 60^{\star}$ & $11 \cdot 63$ \\
\hline Triacylglycerols ( $\mu \mathrm{mol} / \mathrm{g}$ wet liver) & $45 \cdot 70$ & $7 \cdot 29$ & $40 \cdot 91$ & 8.02 & $31 \cdot 84^{*}$ & $7 \cdot 61$ & $32 \cdot 47^{\star}$ & 8.03 \\
\hline
\end{tabular}

BW, body weight.

Mean values were significantly different from those of the other groups: ${ }^{\star} P<0.05$.

For details of diets and procedures, see p. 314 of proofs. 
Table 7. Faecal total bile acids, cholesterol, coprostanol and coprostanone excretion by rats supplemented with Chinese soft-shelled turtle whole egg powder (TE) for 24 weeks

(Mean values with their standard deviations for ten animals per group, unless indicated otherwise)

\begin{tabular}{|c|c|c|c|c|c|c|}
\hline & \multicolumn{2}{|c|}{$0 \mathrm{~g} \mathrm{TE} / \mathrm{kg} \mathrm{BW}$} & \multicolumn{2}{|c|}{$1.5 \mathrm{~g} \mathrm{TE} / \mathrm{kg} \mathrm{BW}$} & \multicolumn{2}{|c|}{$3.0 \mathrm{~g} \mathrm{TE} / \mathrm{kg} \mathrm{BW}$} \\
\hline & Mean & SD & Mean & SD & Mean & SD \\
\hline Cholesterol intake $(\mu \mathrm{mol} / \mathrm{d})$ & 756 & & 738 & & 761 & \\
\hline Faecal output (g dry weight/d) & $3 \cdot 6$ & & $3 \cdot 8$ & & 3.5 & \\
\hline \multicolumn{7}{|l|}{ Faecal bile acids excretion $†$} \\
\hline ( $\mu \mathrm{mol} / \mathrm{g}$ dry faeces) & $16 \cdot 91$ & 3.81 & $21 \cdot 37^{\star}$ & 4.80 & $21 \cdot 12^{*}$ & $2 \cdot 12$ \\
\hline$(\mu \mathrm{mol} / \mathrm{d})$ & $60 \cdot 84$ & & $81 \cdot 21$ & & 73.92 & \\
\hline \multicolumn{7}{|l|}{ Faecal total neutral steroids excretion $\ddagger$} \\
\hline ( $\mu \mathrm{mol} / \mathrm{g}$ dry faeces) & 39.58 & $2 \cdot 29$ & $96 \cdot 13^{\star *}$ & 4.08 & $73 \cdot 83^{\star \star}$ & $4 \cdot 76$ \\
\hline$(\mu \mathrm{mol} / \mathrm{d})$ & $142 \cdot 49$ & & 365.29 & & $258 \cdot 41$ & \\
\hline \multicolumn{7}{|l|}{ Faecal cholesterol excretion $\ddagger$} \\
\hline ( $\mu \mathrm{mol} / \mathrm{g}$ dry faeces) & $28 \cdot 86$ & $2 \cdot 26$ & $74 \cdot 55^{\star *}$ & 3.51 & $55 \cdot 73^{\star \star}$ & \\
\hline$(\mu \mathrm{mol} / \mathrm{d})$ & $103 \cdot 90$ & & $283 \cdot 29$ & & 195.06 & \\
\hline \multicolumn{7}{|l|}{ Faecal coprostanol excretion $\ddagger$} \\
\hline ( $\mu \mathrm{mol} / \mathrm{g}$ dry faeces) & $10 \cdot 08$ & $1 \cdot 19$ & $19 \cdot 07^{\star *}$ & 1.06 & $16 \cdot 73^{\star *}$ & $2 \cdot 18$ \\
\hline$(\mu \mathrm{mol} / \mathrm{d})$ & $36 \cdot 29$ & & $72 \cdot 47$ & & 58.56 & \\
\hline \multicolumn{7}{|l|}{ Faecal coprostanone excretion $\ddagger$} \\
\hline ( $\mu \mathrm{mol} / \mathrm{g}$ dry faeces) & 0.64 & 0.28 & $2 \cdot 51^{*}$ & 0.16 & 1.37 & 0.58 \\
\hline$(\mu \mathrm{mol} / \mathrm{d})$ & $2 \cdot 30$ & & 9.53 & & 4.80 & \\
\hline Faecal total steroids excretion§ $(\mu \mathrm{mol} / \mathrm{d})$ & 203.33 & & $446 \cdot 50$ & & $332 \cdot 33$ & \\
\hline Cholesterol apparent absorption $\|(\mu \mathrm{mol} / \mathrm{d})$ & $552 \cdot 67$ & & $291 \cdot 5$ & & 428.67 & \\
\hline Dietary cholesterol apparently absorbed $(\%)$ & $73 \cdot 10$ & & 39.50 & & $56 \cdot 33$ & \\
\hline
\end{tabular}

BW, body weight.

Mean values were significantly different from those of the control $(0 \mathrm{~g} \mathrm{TE} / \mathrm{kg} \mathrm{BW})$ group: ${ }^{*} P<0.05,{ }^{\star \star} P<0.01$

†The number of samples determined was eight.

$\ddagger$ The number of samples determined was six.

$\S$ Faecal total steroids excretion $=$ faecal total neutral steroids excretion + faecal bile acids

\| Cholesterol apparent absorption $=$ cholesterol intake-total steroid excretion.

I Percentage dietary cholesterol apparently absorbed $=100 \times$ (cholesterol intake-total steroids excretion)/cholesterol intake.

For details of diets and procedures, see p. 314 of proofs.

study, liver CYP7A1 mRNA level was up-regulated by TE supplementation. This may be the mechanism whereby TE could reduce serum cholesterol.

LXR- $\alpha$ is an oxysterol-activated receptor. In the present study, TE supplementation significantly increased liver LXR- $\alpha$ mRNA level at the dose of $3.0 \mathrm{~g} / \mathrm{kg}$ BW. Activated LXR- $\alpha$ could induce expression of a small set of target genes that includes murine CYP7A1, which results in increased synthesis of primary bile acids (Edwards et al. 2002). LXR- $\alpha$ knockout mice fed a high-cholesterol diet accumulate hepatic cholesterol as a result of an inability to induce expression of CYP7A1, the enzyme controlling the rate-limiting step in bile acid synthesis (Peet et al. 1998). There may be some special factors in TE that can activate the expression of LXR- $\alpha$.

TE is a new food resource that contains abundant phosphatidylcholine $(2610 \mathrm{mg} / 100 \mathrm{~g}$ ) and PUFA (fatty acid composition is given in Table 1), which are both cholesterol-lowering factors in food, but the cholesterol content is low $(850 \mathrm{mg} / 100 \mathrm{~g})$. Although phosphatidylcholine plays an important role in intestinal lipid absorption by enhancing micellar lipid solubility and providing the surface coat for the formation of chylomicrons, numerous in vitro studies have shown that phosphatidylcholine inhibits cholesterol uptake. Jiang et al. (2001) reported that egg phosphatidylcholine could markedly lower the lymphatic absorption of cholesterol in vivo. In the present study, TE decreased cholesterol absorption and then increased cholesterol faecal excretion, which might have arisen because of the large content of phosphatidylcholine in TE. Studies in rats and other animal models (Grundy, 1986; Kris-Etherton et al. 1999; Lopez-Miranda et al. 2000) have suggested that dietary MUFA have a potential lipid-lowering effect. There are many studies (e.g. Willett et al. 1995) that support the positive effects of the intake of fish oil (mainly rich in PUFA) on lowering blood lipids. TE is a kind of traditional food in which MUFA and PUFA are both abundant. It is our future work to determine which acts as the cholesterol-lowering agent.

In summary, the present study demonstrates that TE has serum cholesterol-lowering effects in Sprague-Dawley rats. This effect is mediated by enhancing bile acid synthesis and faecal excretion of neutral and acidic steroids. However, because cholesterol

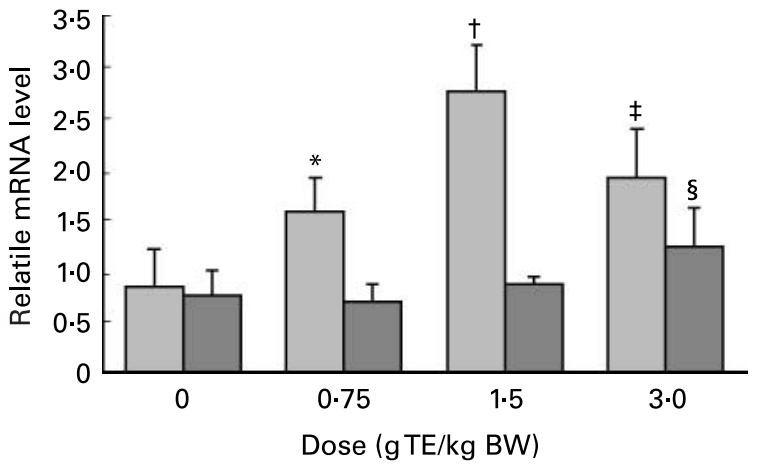

Fig. 1. Hepatic concentration of cytochrome P450, family 7 , subfamily $A$ polypeptide $1(\square)$ and liver $X$ receptor $\alpha(\square)$ in rats supplemented with Chinese soft-shelled turtle whole egg powder (TE) at different doses (BW, body weight) for 24 weeks. mRNA levels were normalized to the values of glyceraldehyde-3-phosphate dehydrogenase. Values are means with their standard deviations shown by vertical bars for three animals per group. Mean values were significantly different from those of the control $(0 \mathrm{~g} \mathrm{TE} / \mathrm{kg} \mathrm{BW})$ group: ${ }^{*} P=0.062 ; \dagger P=0.000 ; \ddagger P=0.013 ; \S P=0.016$ 
metabolism in rats is very different from that in human and other species, future studies will be conducted in man. The mechanisms by which TE lowers plasma cholesterol need to be further characterized and the special functional factors in TE need to be identified.

\section{Acknowledgements}

We duly acknowledge the financial support received from the trans-century training programme foundation for talents by the State Education Commission of the People's Republic of China (200103).

\section{References}

Berge RK, Flatmark T \& Osmundsen H (1984) Enhancement of longchain acyl-CoA hydrolase activity in peroxisomes and mitochondria of rat liver by peroxisomal proliferators. Eur J Biochem 141, 637-644.

Blair RM, Appt SE, Bennetau-Pelissero C, Clarkson TB, Anthony MS, Lamothe V \& Potter SM (2002) Dietary soy and soy isoflavones have gender-specific effects on plasma lipids and isoflavones in golden Syrian F1B hybrid hamsters. J Nutr 132, 3585-3592.

Consensus Conference (1995) Lowering blood cholesterol to prevent heart disease. JAMA 253, 2080-2086.

Edwards PA, Kennedy MA \& Mak PA (2002) LXRs; oxysterol-activated nuclear receptors that regulate genes controlling lipid homeostasis. Vascul Pharmacol 38, 249-256.

Folch BJ, Lees M \& Stanley GHS (1957) A simple method for the isolation and purification of total lipids from animal tissues. $J$ Biol Chem 226, 497-507.

Fukushima M, Nakano M, Morii Y, Ohashi T, Fujiwara Y \& Sonoyama K (2000) Heptic LDL receptor mRNA in rats is increased by dietary mushroom (Agaricus bisporus) fiber and sugar beet fiber. J Nutr 130, 2151-2157.

Garg ML, Blake RJ \& Wills RB (2003) Macadamia nut consumption lowers plasma total and LDL cholesterol levels in hypercholesterolemic man. J Nutr 133, 1060-1064.

Grundy SM (1986) Comparison of monounsaturated fatty acids and carbohydrates for lowering plasma cholesterol. N Engl J Med 314, 745-748.

Huff MW \& Carroll KK (1980) Effects of dietary protein on turnover, oxidation, and absorption of cholesterol, and on steroid excretion in rabbits. J Lipid Res 21, 546-548.

Jiang Y, Noh SK \& Koo SI (2001) Egg phosphatidylcholine decreases the lymphatic absorption of cholesterol in rats. J Nutr 131, 2358-2363.

Kern M, Ellison D, Marroquin Y, Ambrose M \& Mosier K (2002) Effects of soy protein supplemented with methionine on blood lipids and adiposity of rats. Nutrition 18, 654-659.

Kramer JA, LeDeaux J, Butteiger D, Young T, Crankshaw C, Harlow H, Kier L \& Bhat BG (2003) Transcription profiling in rat liver in response to dietary docosahexaenoic acid implicates stearoyl-coenzyme A desaturase as a nutritional target for lipid lowering. J Nutr 133, 57-66.

Kris-Etherton PM, Pearson TA, Wan Y, Hargrove RL, Moriarty K, Fishell V \& Etherton TD (1999) High-monounsaturated fatty acid diets lower both plasma cholesterol and triacylglycerol concentrations. Am J Clin Nutr 70, 1009-1015.

Kritchevsky D, Tepper S, Czarnecki SK \& Klurfeld DM (1982) Atherogenicity of animal and vegetable protein, influence of the lysine to arginine ratio. Atherosclerosis 41, 429-431.

Lopez-Miranda J, Gomez P, Castro P, Marin C, Paz E, Bravo MD, Blanco J, Jimenez-Pereperez J, Fuentes F \& Perez-Jimenez F (2000) Mediterranean diet improves low density lipoprotein susceptibility to oxidative modifications. Med Clin (Barc) 115, 361-365.
Madsen L, Froyland L, Dyroy E, Heiland K \& Berge RK (1998) Docosahexaenoic and eicosapentaenoic acids are differently metabolized in rat liver during mitochondria and peroxisome proliferation. J Lipid Res 39, $583-593$.

Noh SK \& Koo SI (2003) Egg sphingomyelin lowers the lymphatic absorption of cholesterol and $\alpha$-tocopherol in rats. $J$ Nutr 133, $3571-3577$.

Peet DJ, Turley SD, Ma W, Janowski BA, Lobaccaro JM, Hammer RE \& Mangelsdorf DJ (1998) Cholesterol and bile acid metabolism are impaired in mice lacking the nuclear oxysterol receptor LXR $\alpha$. Cell 93, 693-704.

Potter SM (1995) Overview of proposed mechanisms for the hypocholesterolemic effect of soy. J Nutr 125, Suppl., 606S-611S.

Qiu Y, Cavelier L, Chiu S, Yang X, Rubin E \& Cheng JF (2001) Human and mouse ABCA1 comparative sequencing and transgenesis studies revealing novel regulatory sequences. Genomics 73, 66-76.

Russell DW \& Setchell KD (1992) Bile acid biosynthesis. Biochemistry 31, 4737-4749.

Schneider CL, Cowles RL, Stuefer-Powell CL \& Carr TP (2000) Dietary stearic acid reduces cholesterol absorption and increases endogenous cholesterol excretion in hamsters fed with cereal-based diet. J Nutr 130, 1232-1238.

Setchell KDR, Lawson AM \& Tanida N (1983) General methods for the analysis of metabolism profiles of bile acids and related compounds in feces. J Lipid Res 24, 1085-1091.

Sirtori CR, Lovati M-R, Manzoni C, Castiglioni S, Duranti M, Magni C, Morandi S, D'Agostina A \& Arnoldi A (2004) Proteins of white lupin seed, a naturally isoflavone-poor legume, reduce cholesterolemia in rats and increase LDL receptor activity in HepG2 cells. J Nutr 134, 18-23.

Spady DK, Cuthbert JA, Willard MN \& Meidell RS (1995) Adenovirusmediated transfer of a gene encoding cholesterol $7 \alpha$-hydroxylase into hamsters increases hepatic enzyme activity and reduces plasma total and low density lipoprotein (LDL) cholesterol. J Clin Invest 96, 700-709.

Steffensen KR, Nilsson M, Schuster GU, Stulnig TM, Dahlman-Wright K \& Gustafsson JA (2003) Gene expression profiling in adipose indicates different transcriptional mechanisms of liver $\mathrm{X}$ receptor $\alpha$ and $\alpha$, respectively. Biochem Biophys Res Commun 310, 589-593.

Sugiyama K, Ohkawa S \& Muramatsu K (1986) Relationship between amino acid composition of diet and plasma cholesterol level in growing rats fed a high cholesterol diet. J Nutr Sci Vitaminol 32, 413-423.

Tammi A, Ronnemaa T, Valsta L, Seppanen R, Rask-Nissila L, Miettinen TA, Gylling H, Viikari J, Anttolainen M \& Simell O (2001) Dietary plant sterols alter the serum plant sterol concentration but not the cholesterol precursor sterol concentrations in young children (the STRIP study). J Nutr 131, 1942-1945.

Tomotake H, Shimaoka I, Kayashita J, Yokoyama F, Nakajoh M \& Kato $\mathrm{N}$ (2000) A buckwheat protein product suppresses gallstone formation and plasma cholesterol more strongly than soy protein isolate in hamsters. J Nutr 130, 1670-1674.

Wergedahl H, Liaset B, Gudbrandsen OA, Lied E, Espe M, Muna Z, Mork S \& Berge RK (2004) Fish protein hydrolysate reduces plasma total cholesterol, increases the proportion of HDL cholesterol, and lowers acyl-CoA:cholesterol acyltransferase activity in liver of Zucker rats. J Nutr 134, 1320-1327.

Willett WC, Sacks F, Trichopoulou A, Drescher G, Ferro-Luzzi A, Helsing E \& Trichopoulos D (1995) Mediterranean diet pyramid: a cultural model for healthy eating. Am J Clin Nutr 61, Suppl., 1402S-1406S.

Yokogoshi H, Mochizuki H, Nanami K, Hida Y, Miyachi F \& Oda H (1999) Dietary taurine enhances cholesterol degradation and reduces serum and liver cholesterol concentrations in rats fed a high-cholesterol diet. J Nutr 129, 1705-1713.

Zhang X \& Beynen AC (1993) Influence of dietary fish protein on plasma and liver cholesterol concentrations in rats. Br J Nutr 69, 767-777. 